\title{
Syncretism of Confucianism, Buddhism and Daoism in Liáozhāi Zhìỳi in Terms of Filial Piety
}

\author{
Aiqing Wang \\ University of Liverpool, United Kingdom \\ corresponding author : Aiqing.Wang@liverpool.ac.uk \\ Received: 5-2-2021; Revised: 15-4-2021; Accepted: 31-5-2021 \\ DOI: $10.31291 /$ hn.v10i2.595
}

\begin{abstract}
Liáozhāi Zhìì is one of the representative compilations in the genre of zhìgài 'strange writing' during the Qing (1644-1912) era, and it conveys filial piety through narration and authorial commentary. This research scrutinizes narratives regarding the preponderant construal of filial piety, so as to explore the harmonious contemporaneous of religious thinking and behavior in Qing China. This research conducts interpretative and hermeneutic research on four narratives in Liáozhāi Zhìyi, namely, $X$ i Fāngpíng, Lè Zhòng, Sìshí Qiān, and Qiánbǔ Wü, and also refers to classic treatises regarding filial piety. Given the fact that narratives in Liáozhāi Zhìì themed by or appertaining to filial piety entail elements of three religions simultaneously. This study propounds that it illuminates amalgamation of Confucianism, Buddhism and Daoism, i.e. sānjiàohéȳi, in seventeenth-century China.
\end{abstract}

Keywords: Liáozhāi Zhìỳ̀, zhìguài genre, Confucianism, Buddhism, Daoism, filial piety 


\begin{abstract}
Abstrak
Liáozhāi Zhìyi adalah salah satu kompilasi representatif dalam genre zhìguài 'tulisan aneh' selama era Qing (1644-1912), dan menyampaikan kesalehan anak melalui narasi dan komentar penulis. Penelitian ini, menelaah narasinarasi tentang penafsiran yang lebih besar tentang bakti, untuk mengeksplorasi keserasian pemikiran dan perilaku keagamaan di Qing Cina. Penelitian interpretatif dan hermeneutik ini dipusatkan pada empat narasi dalam Liáozh āi Zhìỳ, yaitu, Xí Fāngpíng, Lè Zhòng, Sìshí Qiān, dan Qiánbǔ Wū, dan kajian ini juga merujuk pada risalah klasik tentang berbakti. Mengingat fakta bahwa narasi dalam Liáozhāi Zhìyi bertema atau berkaitan dengan berbakti mengandung unsur-unsur dari tiga agama secara bersamaan, kajian ini mengusulkan penggabungan Konfusianisme, Buddhisme dan Taoisme, yaitu sānjiàohéȳi, di Cina abad ketujuh belas.
\end{abstract}

Kata kunci: Liáozhāi Zhìyì, genre zhìguài, Konfusionisme, Buddha, Taoisme, bakti anak

\title{
Introduction
}

Classical Chinese literature abounds with illustrious fiction labeled as 志怪 zhìguài, viz. 'strange writing' or 'accounts of miraculous paranormality and abnormality', which evolved into a full-fledged genre since Six Dynasties (222-589 AD) (DeWoskin 1977, Campany 1991, Chiang 2005: 12-13, Shang 2018). Zhìguài writing features supernatural phenomena, occurrences, and creatures, with an emphasis placed on mythical figures, sages, sovereigns, practitioners of shamanism, and esoteric arts, as well as divinities, fauna, flora, and mythological events affiliated to topographically listed sites (Campany 1996: 99, Chen 2002). Zhìguài narratives are cumulated from distinct sources, ranging from historiographical collections, religious texts and palace archives, to shrine inscriptions, local legends and alleged eyewitnesses (Kao 1985: 28, Zeitlin 1993: 4-5, Campany 1996: 151, Zhang 2014: 1).

The earliest extant zhìguài compilation is 搜神记 Sōushénjì 'In Search of the Supernatural: The Written Record' by a court historian 干宝 Gān Băo (?-360 AD), which occurred before Six Dynasties in circa 350 AD. 
Syncretism of Confucianism, Buddhism and Daoism ...

This archetype of zhiguài writing has palpably impinged upon following collections in the Qing (1644-1912) era (DeWoskin and Crump 1996: xxv, Xie 2014), including 子不语 Zǐbùyŭ 'What the Master Would not Discuss' published in 1788 by an unconventional skeptic-iconoclast and gastronomist called 袁枚 Yuán Méi (1716-1798) (Chan 1991, Clart 1996, Louie and Edwards 1996: xxiii, Tucker 1997, Santangelo and Yan 2013: vii-viii) and 阅微草堂笔记 Yuèwēi Căotáng B Ǐji 'Jottings from the Grass Hut for Examining Minutiae' by an elite politician and philosopher 纪昀 Jì Yún (1724-1805) (Chan 1993, 1998: 8, Riegel 2010, Chang 2013).

The pinnacle of zhiguài compilations in the Qing dynasty is unanimously regarded to be an epoch-making masterpiece 聊斋志异 Liáozhāi Zhìyi 'Strange Tales/Stories from a Chinese Studio' or 'Strange Tales from the Liáozhāi Studio', the themes, plot lines, and narrative styles of which are also profoundly inspired by Sōushénjì (Yuan 1999, Yuan and Xu 2000: 177, Teo 2006, Nienhauser 2010: 118, Cook 2014) as well as 传奇 chuánqí 'marvel tales' or 'transmissions of the strange' of the Tang (618-907) era (Bush 2001: 152, Zhao 2005: 31 32, Nienhauser 2010: xiii). Liáozhāi Zhìyi (henceforth Liáozhāi) is a posthumously Públished chef-d'oeuvre of 蒲松龄 Pú Sōnglíng (16401715), a prolific intellectual of iconic fame in Classical Chinese literature (Yuan 1984, Chang and Chang 1998: 1, 42, 2004: 130, Teo 2006, Cook 2014, Hughes et al 2016: 47).

Although Liáozhāi is composed in the vernacular style of the seventeenth century and expounds anomalies and prodigies, it exhibits similitude in terms of narrative rhetoric with the monumental 史记 ShI $j i$ 'Records of the Grand Historian' composed by a court scribe and 
astrologer 司马迁 Sīmă Qiān (circa 145-87 BC) in circa 90 BC (Li 2004: 319, Kern 2015). Analogous to Shijji, a prototype shaping the subsequent development of the narrative tradition (Barr 2007), Liáozhāi integrates three components, viz. autobiography, narrative, and commentary (Zeitlin 1988: 41). Pú creates a persona called 异史氏 $Y i$ sh $\check{I} S h i$ 'the Historian of the Strange' pertaining to the title of Sima Qian, i.e. 太史公 täishǏ gōng ‘the Grand Historian’ (Li 1985, Yu 1987) and appends third-person authorial comments to a total number of 149 tales, introduced by an expression 异史氏日 Yish š Shì yue 'the Historian of the Strange says' (Zhao 1984), which is on a par with the style of ShIjji (Li 2004: 319, He 2011). The authorial commentary assumes a preponderant role in Liáozhāi, in that it constitutes a frame elaborating the narrative core and themes, and epitomizes Pú's insights into characters, storylines, and counsel for readers (Zhang 1989, Zheng 2001, Barr 2007).

\section{Method}

In this paper, I investigate the epoch-making zhìguài classic Liáozhāi. By scrutinizing narratives appertaining to the preponderant construal of filial piety, I postulate that Liáozhāi embodies the amalgamation of Confucianism, Buddhism, and Daoism in pre-modern China.

In Liáozhäi, there are approximately fifty anecdotes implicitly or explicitly alluding to filial piety, the significance of which is illustrated by an array of benefits: being a filial son can be awarded affluence, officialship, longevity, immortality, as well as offspring and their blessing (Yang 2011). In this paper, I conduct interpretative and hermeneutic research on four narratives in Liáozhāi, namely, 席方平 $X \hat{i}$ 
Syncretism of Confucianism, Buddhism and Daoism ...

Fāngping, 乐仲 Lè Zhòng, 四十千 Sìshi Qiān, and 钱卜巫 Qiánbǔ Wū, and I also refer to classic treatises regarding filial piety.

Moreover, with its literary prominence, artistic value, and narrative skills, Liáozhāi and its author Pú have received a prodigious amount of interpretative, hermeneutic, and biographical scrutiny, reflected by the prosperous transnational critical industry dubbed as 蒲学 Pú-xué or 仰 斋学 Liáozhāi-xué that literally means ‘Pú/Liáozhāi-ology’ (Barr 1984, Li 2005, Wang 2006, Fan and Liu 2019, Zou 2019). In this paper, I also draw on 'Pú/Liáozhāi-ology' literature.

\section{Literature Review}

In Confucianism, filial piety (孝 xiào) is construed as a pivotal virtue (see Ivanhoe 2000: 2, 2007, Chan and Tan 2004, Nuyen 2004, among many others), one of the underlying and overarching precepts of the moral system and the anthropological source of ethically evaluative sentiment (Yao 1995, Hwang 1999, Ikels 2004: 187-191, Larm 2012, Van Norden 2019). Filial piety, along with fraternal responsibility in the family and loyalty (忠 zhōng) to the country, function as derived virtues and underpin 仁 rén 'benevolence; humanity' which is one of the 五常 wǔ cháng 'five constants/relationships' (Cheng and Cheng 1989: 105, Wilkinson 1996, Huang 2013, Chen 2018, Tan 2018) and the fundamental credo in the entire Confucian school of ethical thought (Ames 1991, 2011, Neville 2011, Slingerland 2011, Chen 2013, Wong 2020).

Kinship establishment is a foundational constituent of Buddhist practice, in that familial ties are capable of performing social labor, and family membership serves as an influential motivational tool for aspiring Buddhists (Wilson 2013) — even ordination cannot cease the bonds 170 | VOL. 10 NO. 2 DECEMBER 2021 
between renouncers and their families (Clarke 2009, Xing 2010). Buddhist ethos also entails filial piety, which is reflected by scriptures that depict Buddhists conducting heroic acts to benefit their parents (Ch'en 1968, Teiser 1988: 92-94), as well as imperatives to repay parents' kindness (Ch'en 1973, Sung 2003, Kunio 2004). Additionally, Buddhist filial devotion is marked by its overarching construal of reincarnation: since deceased ancestors could exist in various forms by reincarnation, Buddhists, who practice universal compassion covering animals, hell beings, and denizens of diverse post-mortem realms, can thus thoroughly accommodate reincarnated ancestors (Wilson 2013, 2014). Moreover, filial piety is a pivotal aspect of Buddhist ethical teachings (Strong 1983, Xing 2005). According to medieval Buddhist propaganda, one is obliged to take the fate of one's parents in the afterlife into consideration, so the most filial conduct is to become a monk or nun, or at least make a plenitude of donations to monastic institutions (Cole 1998: 62, 235, Despeux and Kohn 2003: 145-146): inscriptional and textual evidence illuminates that both monastics and laity make donations to benefit their living and deceased parents (Schopen 1984).

Filial piety plays a preponderant role in Daoist ideology: as prescribed by a medieval Daoist classic 太平经 Tàipíng Jing 'Scripture on Great Peace', 天下之事, 孝为上第一 tiānxià zhī shì, xiào wéi shàngdìȳ 'among the activities of this world, filial piety is supreme and of first rank' (Wang 1960: 592, Hendrischke 2007: 363, Liao 2013, Eskildsen 2015: 32). Filial impiety, however, triggers karma that renders Daoist followers subject to hell, abominable rebirth, and inability to attain immortality (Kohn 2004). The establishment of Daoist filial piety is inspired by and hence inextricably intertwined with Confucian filial 
piety (Zheng and Zhan 2011), in that it further enriches and expounds its Confucian counterpart, as exemplified by a statement that 人亦天地 之子也 rén yì tiāndì zhĩż̃ yě 'men are children of heaven and earth', proclaimed by Taiping Jing (Wang 1960: 406, Hendrischke 2007: 228, Liao 2013). Humans are also perceived to have an especially close relationship with their ancestors, so the acts of ancestors directly impinge upon the fate of descendants, referred to as inherited evil that is constituted of various concepts of ancestral wrath, personal retribution, and collective punishments (Chen 1986, Brokaw 1991: 28, Hendrischke 1991, Kohn 2004).

As a national faith of China, the construct of 三教合一 sānjiàohéȳ 'the unity of Confucianism, Buddhism and Daoism' initially occurred before the Tang dynasty (Brook 1993, Gong and Gong 2010), based on the integration among and condominium of Confucianism, Daoism, and Buddhism that is of foreign origin (Fan and Whitehead 2011, Shahar 2013). Since it first attained popularity during the late Ming (1368-1644) era (Duara 2008), this late imperial gentry syncretism has been underpinning a scheme in which Confucianism is regarded as the mainstay, while Daoism and Sinicised Buddhism serve as branches (Han 2011, Shan 2012c, Sun 2012). Despite divergent canons, liturgies, and venues (Huang 1998, Adler 2002), such harmonization of Confucianism, Buddhism, and Daoism is referred to as syncretism: as propounded by a proverb from a 1605 novel 封神演義 Fēngshén Yănyi 'Investiture of the Gods' that is of massive and grandiose conception (Kao 2002, Lu 2011), '[t]he three teachings - the gold and cinnabar of Daoism, the relics of Buddhist figures, as well as the Confucian virtues of humanity and righteousness - are basically one tradition' (Plopper 1926: 16, Teiser 1996: 3). 


\section{Result and Discussion}

A paradigm conveying the Confucian creed of filial piety in Liáozhāi is 席方平 Xí Fāngping, in which the protagonist Xí Fāngpíng enters the underworld four times and endures savage infliction to redress the injustice and exploitation imposed on his father (Zhang 2003); other filial deeds in Liáozhāi include the personal sacrifice of wellbeing, enjoyment, freedom, status, and life (Yang 2011).

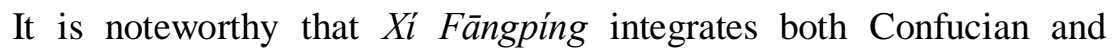
Buddhist canons. In author's comment introduced via the expression $Y i$ shř Shì yue, 'the Historian of the Strange says', a prominent Buddhist concept of 净土 jingtǔ 'Pure Land' signifying the transcendent realm of Buddhas and bodhisattvas (Hirota 2000, Leeming 2002, 2005, Keown 2004) is included, yet in the posterior context, salient Confucian virtues of zhōng and xiào, which serve as two interwoven components of rén, are also mentioned (Example (1)).

(1) 异史氏曰: “人人言净土, 而不知生死隔世, 意念都迷, 且不 知其 所以来, 又乌知其所以去; 而况死而又死, 生而复生者乎? 忠孝志 定, 万劫不移, 异哉席生, 何其伟也!”

Yì shǏ shì yuē: 'Rén rén yán jìng tǔ, ér bù zhī shēng sĩ gé shì, yì

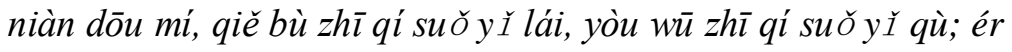
kuàng š ér yòu š̆, shēng ér fù shēng zhě hū? Zhōng xiào zhì dìng, wàn jié bù yí, yì zäi xí shēng, hé qí wěi yě!'

'The Historian of the Strange says: "Everybody talks about Pure Land, yet nobody understands that the disparity between life and death is insurmountable, rendering living people bewildered about departures and destinations, not to mention repeatedly revived people. Xi's determination to loyalty and filial piety is extremely adamantine. How wondrous and great he is!"'

(Liáozhāi. Xỉ Fāngpíng. Trans. Mine) 
Syncretism of Confucianism, Buddhism and Daoism ...

An analogous paradigm regarding Confucian filial piety in Liáozhāi is entitled 乐仲 Lè Zhòng, in which the protagonist Lè Zhòng worships his deceased mother rather than a Buddhist statue, as in Example (2). Confucian promulgation of ancestral worship is ascribed to conventional institutions, in that offering sacrifices to ancestors leads to reverence for elder and senior members in familial and societal hierarchies (Hall and Ames 1996: 64-65, Nichols 2011, Shan 2012a: 25-27), so Confucian scholar-rulers endeavor to harness subordinates for kinship solidarity, community stability and social harmony (Cohen 1992, Chen 2018). Moreover, ancestral worship constructs indebtedness and interdependence and reinforces a reciprocal relation-faith pattern between ancestors and worshipers (Yang 1976: 357-358, Shun 2002).

(2) 父早丧, 遗腹生仲, 母好佛, 不茹荤酒。仲既长, 嗜饮善啖, 窃腹 诽母, 每以肥甘劝进。母咄之。后母病, 弥留, 苦思肉。 仲急无 所得肉, 刲左股献之。病稍痏, 悔破戒, 不食而死。仲 哀悼益切, 以利刃益刲右股见骨。家人共救之, 裹帛敷药, 寻 愈。心念母苦 节, 又恸母愚, 遂焚所供佛像, 立主祀母。醉后, 辄对哀哭。

Fù zăo sàng, yí fù shēng zhòng, mǔhăo fó, bù rúhūn jiǔ. Zhòng

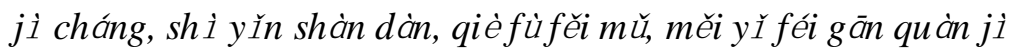
n. Mǔ duō zhī. Hòu mǔbìng, mí liú, kǔ sī ròu. Zhòng jí wú suǒ dé ròu, kū zuǒ gǔxiàn zhī. Bìng shāo chài, huǏ pò jiè, bù shí

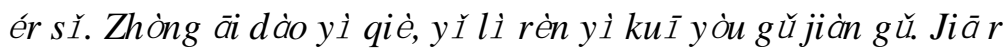
én gòng jiù zhī, guǒ bófū yào, xún yù. Xĩn niàn mǔ kǔ jié, yòu $t$ òng mǔ yú, suì fén suǒ gòng fó xiàng, lì zhǔ sì mǔ. Zuì hòu, zh é $d u$ i āi $k \bar{u}$.

'Le Zhong was a posthumous child. Being a devoted Buddhist, Zhong's mother had been a vegetarian refraining from drinking. Zhong grew up to be an alcoholic and gastronome who disdained his mother's practice, so he often induced her to try gourmet food. Such acts were always rebuffed sternly. Later, his mother was in extremism 
and eager for meat. Zhong could not find any meat immediately, so he cut some flesh off his left thigh to feed his mother. When his mother slightly recovered, she was so contrite to violate the abstinence that she starved herself to death. The mournful Zhong cut his right thigh deep to the bone with a sharp knife; he was rescued and cured by his family and recovered gradually. Zhong grieved over his mother's abstinence and stubbornness, so he burned the Buddhist statue and worshipped her instead. He often wept in front of her memorial tablet after drunkenness.'

(Liáozhāi. Lè Zhòng. Trans. Mine)

As can be seen from Example (2), apart from orthodox Confucian norms prescribing widow chastity (Mann 2002, Theiss 2002), the anecdote depicts Buddhist practices including vegetarianism and propitiation; moreover, in the rest of the narrative, Buddhist elements such as sexual abstinence and lotus are also expounded. More significantly, the portrayal of cutting off one's flesh in (2) is aberrant from the Confucian tenet of filial piety but accords with Buddhist philosophy. As proscribed by 孝经 Xiào Jing 'Classic of Filial Piety', one of the thirteen Confucian classic treatises (Goldin 2015: 35, Yan 2017, Yang 2017), the inception of filial piety lies in preserving one's own body, hair, and skin, all of which are bestowed upon by one's parents. However, a Buddhist apologetic work, 牟子理惑论 Móuzİ Lǐhuò Lùn 'Mouzi on the Settling of Doubts' points out the importance of weighing the circumstances, and argues that to attain 'great virtue', one is not expected to stringently comply with trivial ritual details regarding hurting one's body (Kunio 2004).

Additionally, the protagonist's reverence for his mother in Lè Zhòng embodies Daoist (aka Taoist) filial piety that places an emphasis on mothers. To be more specific, in stark contrast to Confucian patriarchal ideals epitomized by 三从四德 sān cóng sì dé 'Three Obediences and 
Syncretism of Confucianism, Buddhism and Daoism ...

Four Virtues' (Gao 2003, Rosenlee 2006: 90-92, Lee 2009), Daoist teachings recognize the feminine role in the ethical system and deploy a metaphorical representation to link female reproduction to the oneness of the universe and the essence of Dao (Despeux and Kohn 2003: 1-2, Zheng and Zhan 2011, Cook 2015).

Apart from Confucian precepts, Liáozhāi abounds with Buddhist canons, embodied by: 1) conceptions of reincarnation, hell, and karma; 2) the spirit of equality; and 3) mysticism (Qin 2004, Li 2011, Yang 2016).

A narrative 四十千 Sishi Qiān 'Forty Thousand' conveys a karmatic belief through a Buddhist monk that children are to collect the debt from parents incurred during their previous incarnation (Example 3). In the story, an affluent man has a dream about owing another man forty thousand, and upon he wakes up, his wife delivers a boy, so he allocates forty thousand as the maintenance to raise this newborn. Three years later, there is only seven hundred left, so he informs the boy of his incoming decease. The boy immediately breathes his last, and the remaining money exactly covers his funeral cost. Furthermore, as can be seen from Example (3), the authorial commentary accords with another related Buddhist ideal that children are to repay the debt of gratitude to their parents (Tan 2011).

（3）昔有老而无子者, 问诸高僧。僧曰: “汝不欠人者, 人又不 欠汝者, 乌得子?” 盖生佳儿, 所以报我之缘; 生顽儿, 所以取我 之债。生 者勿喜, 死者勿悲也。

Xĩ yǒu lăo ér wú zĭ zhě, wèn zhū gão sēng. Sēng yuẽ: 'Rŭbù qiàn rén zhě, rén yòu bù qiàn rǔ zhĕ, wū de zi ?' Gäi shêng jiā ér, suǒ yĭ bào wǒ zhī yuán; shēng wán ér, su ǒ y y qǔ wǒ zhī zhài. Shèng zhě wù xŭ, sĭ zhě wù bēi yĕ.

'A childless old man enquired a Buddhist monk about his heirlessness. The monk said: "If you have never owed others and neither have they owed you, how can you have children?" 
Outstanding children are to reward fate; misbehaved children are to dun debt. Do not celebrate for newborns or grieve over decedents.'

(Liáozhāi. Sìshi Qiān. Trans. Mine)

Furthermore, acconsiderable portion of narratives in Liáozhāi can be analyzed as outcomes of non-institutionalized, folk Daoism, embodied by an equality conception entailing conversions of mythical creatures into human beings and mortals into immortals (Li 2013). Moreover, Liáozhāi depicts fairyland, immortals' life, and interaction with mortals (Yang 2004), as well as Daoist priests' avuncular and upright deeds, disparate from those conducted by Buddhist monks (Cheng 2017, Xi 2018).

A tale 钱卜巫 Qiánbǔ Wū in Liáozhāi conveys the Daoist credence that one's conduct affects their offspring (4), parallel to a thought indicated in a divination classic 易经 $Y_{l}$ Jing 'Book/Classic of Changes' that a household acts as an integrated unit in terms of divine blessings and retribution.

(4) 先人有善, 其福未尽, 则后人享之; 先人有不善, 其祸未尽, 则后人亦受之。

Xiān rén yŏu shàn, qí fú wèi jìn, zé hòu rén xi ăng zhī; xiān rén yŏ u bù shàn, qi huò wèi jìn, zé hòu rén yì shòu zhī.

'If forefathers exhibit goodness yet have not enjoyed all the blessing, offspring will inherit it; if forefathers commit vice yet have not suffered all the cataclysms, offspring will also inherit them.'

(Liáozhāi. Qiánbǔ Wū. Trans. Mine)

(5) 积善之家, 必有余庆; 积不善之家, 必有余殊。

Jī shàn zhī jiāa, bì yŏu yú qìng; jī bù shàn zhī jiāa, bì yŏu yú yang. 
'The family that accumulates goodness is sure to have superabundant happiness. The family that accumulates evil is sure to have superabundant misery.'

(Yì Jìng. Trans. Legge 1969: 20)

A distinctive property of Daoist doctrine lies in its quest for longevity and even eternal life (Akahori 1989, Despeux and Kohn 2003: 1, Shan 2012a: 83-88); consequently, Daoist filial piety is featured by children's obligation to obtain physical immortality for their parents (Zheng and Zhan 2011, Liao 2013) as well as their commitment to prolong the life expectancy of their parents (Hendrischke 2007: 303, 363, Zhou 2012). In 席方平 $X i l$ Fāngping depicting Confucian filial piety, the protagonist's filial deed is rewarded by an additional thirty-six years of life for his father (6), which typically indicates the Daoist belief.

（6）念汝子孝义, 汝性良懦, 可再赐阳寿三纪。

Niàn rǔzi xiào yì, rǔxing liáng nuò, kě zài c ì yáng shòu sān jì.

'Given your son's filial piety and your kindness, thirty-six years' additional life will be bestowed upon you.'

(Liáozhāi. Xí Fāngpíng. Trans. Mine)

Furthermore, the protagonist in Xí Fāngpíng also serves as the epitome of Daoist filial commitment and devotion. Filial children in a Daoist sense are obliged to cultivate themselves and thrive (Zheng and Zhan 2011, Liao 2013, Wu 2014). According to a Daoist classic treatise 文昌 孝经 Wénchāng Xiàojīng composed in the Song (960-1279) dynasty (Xiao 1997, Wu 2014, Zhang 2015), filial piety is encapsulated by one's competence in assuming responsibilities, which functions as a prerequisite for empathy with parents, as in Example (7).

(7) 所谓孝子, 欲体亲心, 当先立身。…完厥惺惺体, 尽我所当 务。 


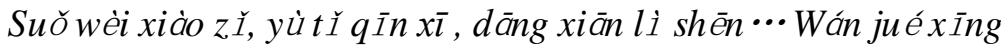

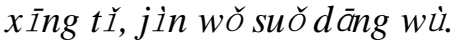

'To empathize with parents, a filial son should first cultivate himself...One should accomplish the self and fulfill responsibilities.'

(Wénchāng Xiàojīng. Shǒushēn. Trans. Mine)

It is worth mentioning that 修身 xiūshēn 'self-cultivation' is also a preponderant Confucian precept about the attainment of individual psychological stability and personal discipline, which lays the foundation for contribution to social life and country governance as a 君 子 jūnzİ 'gentleman; superior/exemplary/virtuous person' (Mou 2009, Judy 2011, Coles 2019). As promulgated in 大学 Dàxué 'Great Learning', one of the Four Books (四书 sìshü) of Confucian Classics, '[t]hose who wished to bring order to their states would first regulate their families. Those who wished to regulate their families would first cultivate their personal lives. Those who wished to cultivate their personal lives would first rectify their minds. Those who wished to rectify their minds would first make their will sincere' ( $\mathrm{Ng} 2009$ : 4, Shan 2012b, Liu and Cao 2014, Wu 2017); as stated in 中庸 Zhōngyōng 'Doctrine of the Mean', 'one who knows how to cultivates his person knows how to govern men; and one who knows how to govern men knows how to govern the states and families of the world' (de Bary and Bloom 1999: 337, Pohl 1999: 85, Zhang 2014, Tan 2017).

\section{Conclusion}

As can be seen from narratives exemplified by Lè Zhòng and Xí Fāngping, Liáozhāi embodies the unification of Confucianism, Buddhism, and Daoism, analogous to a mid-eighteenth-century 
Syncretism of Confucianism, Buddhism and Daoism ...

masterpiece 红楼梦 Hóng Lóu Mèng ('Dream of the Red Chamber/Mansion' or 'Story of the Stone') that I suggest manifests the sanjiaoheyi religious ideology of aristocracy in imperial China under the reign of the Qing dynasty (Wang 2020).

The inclusive religiosity can be reflected in Liáozhāi in terms of its depiction concerning filial piety. Although Xí Fāngping and Lè Zhòng express Confucian filial piety, there are Buddhist terminologies indicated in the narratives. Other tales such as Sishi Qiān and Qiánbǔ W $\bar{u}$ may not entail distinct doctrines simultaneously, whereas they indeed demonstrate that when discussing filial piety, Liáozhāi is not limited to any single religion. On the contrary, Liáozhāi manifests harmonious contemporaneous of religious thinking and behavior in the seventeenth century.

\section{References}

Adler, J. A. (2002). Chinese Religious Traditions. New York: Pearson.

Akahori, A. (1989). Drug Taking and Immortality. In Taoist meditation and longevity techniques, eds. Livia Kohn and Yoshinobu Sakade, 73-98. Ann Arbor: University of Michigan.

Ames, R. T. (1991). The Mencian Conception of Ren Xing: Does It Mean Human Nature? In Chinese Texts and Philosophical Contexts: Essays Dedicated to Angus C. Graham, ed. Henry Rosemont Jr., 143-175. La Salle, IL: Open Court.

Ames, R. T. (2011). Confucian Role Ethics: A Vocabulary. Honolulu: University of Hawaii Press.

Barr, A. (1984). The Textual Transmission of Liaozhai zhiyi. Harvard Journal of Asiatic Studies 44.2: 515-562.

Barr, A. (2007). 'Liaozhai zhiyi' and 'Shiji' . Asia Major 20.1: 133-153.

Brokaw, C. (1991). The Ledgers of Merit and Demerit: Social Change and Moral Order in Late Imperial China. Princeton: Princeton University Press. 
Brook, T. (1993). Rethinking Syncretism: The Unity of the Three Teachings and Their Joint Worship in Late - Imperial China. Journal of Chinese Religions 1: 13-44.

Bush, L. (2001). Asian Horror Encyclopedia: Asian Horror Culture in Literature, Manga, and Folklore. New York: Writers Club Press.

Campany, R. F. (1991). Ghost Matter: The Culture of Ghosts in the Six Dynasties zhiguai. Chinese Literature: Essays, Articles, Reviews 13: $15-34$.

Campany, R. F. (1996). Strange Writing: Anomaly Accounts in Early Medieval China. Albany: State University of New York Press.

Chan, A. and S.-H. Tan. (2004). Introduction. In Filial piety in Chinese thought and history, eds. Alan Chan and Sor-Hoon Tan, 9-16. London: RoutledgeCurzon.

Chan, L. T.-h. (1991). Subjugating Spirits: Yuan Mei's What the Master Would Not Speak Of. Asian Culture 19.4: 40-47.

Chan, L. T.-h. (1993). Narrative as Argument: The Yuewei caotang biji and The Late Eighteenth-Century Elite Discouse on The Supernatural. Harvard Journal of Asiatic Studies 53.1: 25-62.

Chan, L. T.-h. (1998). The Discourse on Foxes and Ghosts: Ji Yun and Eighteenth-Century Literati Storytelling. Hong Kong: The Chinese University of Hong Kong Press.

Chang, C.-s. and S. H.-1. Chang. (1998). Redefining History: Ghosts, Spirits, and Human Society in P'u Sung-ling's World, 1640-1715. Ann Arbor: University of Michigan Press.

Chang, Q. (2013). Qiantan Yuewei caotang biji yu Soushenji zhong sierfusheng gushi de yitong [The Resurrection Stories in 'Notes of the Yuewei Hermitage' and 'In Search of the Supernatural': Similarities and Differences]. Journal of Harbin University 04: 62-65.

Chen, F. (2002). Archetype and Aesthetics of the Fantastic: The Narrative Form in Chinese and French Fiction. Comparative Criticism 24: 239-254.

Chen, J. (1986). Taiping jing zhong de chengfu baoying sixiang [The concepts of cheng, fu and retribution in Taiping jing]. Religious Studies 35-39.

Ch'en, K. (1968). Filial Piety in Chinese Buddhism. Harvard Journal of Asiatic Studies 28: 81-97. 
Ch'en, K. (1973). The Chinese transformation of Buddhism. Princeton: Princeton University Press.

Chen, L. (2013). Virtue Ethics and Confucian Ethics. In Virtue Ethics and Confucianism, eds. Stephen Angle and Michael Slote, 15-27. New York, Abingdon: Taylor \& Francis Group.

Chen, L. (2018). Historical and Cultural Features of Confucianism in East Asia. In Confucianisms for a changing world cultural order, eds. Roger T. Ames and Peter D. Hershock, 102-111. Honolulu: University of Hawaii Press.

Cheng, C. (2017). Liaozhai yu Zibuyu Zhong daoshi xingxiang de yitong fenxi [Similarities and differences of the image of Daoist priests in Liaozhai and Zibuyu]. Select About Essay: 08: 14.

Cheng, H. and Y. Cheng. (1989). Er Cheng Ji [Collected Works of Cheng Brothers]. Beijing: Zhonghua Shuju.

Chiang, S.-c. L. (2005). Collecting the Self: Body and Identity in Strange Tale Collections of Late Imperial China. Leiden; Boston: Brill.

Clarke, S. (2009). Locating Humour in Indian Buddhist Monastic Law Codes: A Comparative Approach. Journal of Indian Philosophy 37.4: 311-330.

Clart, P. (1996). Reviewed Work: Censored by Confucius: Ghost Stories by Yuan Mei. Pacific Affairs 69.3: 408-409.

Cohen, M. L. (1992). Religion in a State Society: China. In Asia: Case Studies in the Social Sciences, ed. Myron L. Cohen, 17-31. New York: M. E. Sharpe, Inc.

Cole, A. (1998). Mothers and Sons in Chinese Buddhism. Stanford: Stanford University Press.

Coles, B. (2019). Guo Xiang and the Problem of Self-Cultivation in Daoist Naturalism. Religions 10: 388.

Cook, C. (2015). 'Mother' (Mu 母) and the Embodiment of the Dao. Journal of Chinese Philosophy 42(1-2): 242-249.

Cook, J. W. (2014). Strange tales of liaozhai. In Encyclopedia of Renaissance literature $\left(2^{\text {nd }}\right.$ ed), ed. James Wyatt Cook. Facts on File.

de Bary, W. T. and I. Bloom. (1999). Sources of Chinese Tradition: From Earliest Times to 1600. New York: Columbia University Press. 
Despeux, C. and L. Kohn. (2003). Women in Daoism. Dunedin: Three Pines Press.

DeWoskin, K. J. (1977). The Six Dynasties Chih-kuai and the Birth of Fiction. In Chinese Narrative, ed. Andrew H. Plaks, 21-52. Princeton: Princeton University.

DeWoskin K. J. and J. I. Crump. (1996). Trans. Introduction. In In Search of the Supernatural: The Written Record, by Gan Bao. Stanford: Stanford University Press.

Duara, P. (2008). Religion and Citizenship in China and the Diaspora. In Chinese Religiosities: Afflictions of Modernity and State Formation, ed. Mayfair Mei-hui Yang, 43-64. Berkeley and Los Angeles: University of California Press.

Eskildsen, S. (2015). Daoism, Meditation, and the Wonders of Serenity: From the Latter Han Dynasty (25-220) to the Tang Dynasty (618907). Albany: State University of New York Press.

Fan, L. and J. D. Whitehead. (2011). Spirituality in a Modern Chinese Metropolis. In Chinese Religious Life, eds. David A. Palmer, Glenn Shive and Philip L. Wickeri, 13-29. Oxford and New York: Oxford University Press.

Fan, Q. and J. Liu. (2019). 'Liaozhai xue' tixi de jiangou ji zhanwang [The construction and development of the 'Liaozhai study' system]. Study on Pu Singling 03.

Gao, X. (2003). Women Existing for Men: Confucianism and Social Injustice against Women in China. Race, Gender \& Class 10.3: 114-125.

Goldin, P. R. (2015). Confucianism. London and New York: Taylor \& Francis Group.

Gong, W. and D. Gong. (2010). Rushidao sanjiao heyi yu sengjia chongbai tuxiang [Unity of Confucianism, Buddhism and Daoism and totems of monks]. Aesthetics 04: 87-89.

Hall, D. L. and R. T. Ames. (1996). Thinking through Confucius. Trans. Yiwei Jiang and Zhilin Li. Nanjing: Jiangsu People's Públishing House.

Han, X. (2011). Quanzhendao sanjiaoheyi de lilun tezheng [Quan zhen dao: a combination of Taoism, Confucianism and Buddhism]. Journal ff Lanzhou University 05: 1-6. 
He, M. (2011). Liaozhai zhong de 'Yishi Shi yue' yu pinglun ['Yishi Shi yue' and comments in Liaozhai]. Journal of Literature and History 04.

Hendrischke, B. (1991). The Concept of Inherited Evil in the Taiping Jing. East Asian History 2: 1-30.

Hendrischke, B. (2007). The Scripture on Great Peace: The Taiping jing and the Beginnings of Daoism. Berkeley, CA: University of California Press.

Hirota, D. (2000). Images of Reality in the Shin Buddhist Path. In Toward a Contemporary Understanding of Pure Land Buddhism: Creating a Shin Buddhist Theology in a Religiously Plural World, ed. Dennis Hirota, 33-72. Albany: State University of New York Press.

Huang, X. (1998). Sanjiaoheyi zai woguo fazhan de guocheng, tedian jiqi dui zhoubian guojia de yingxiang [The development, characteristics and influence on neighbouring countries of sanjiaoheyi in China]. Philosophical Research 08: 25-31.

Huang, Y. (2013). Between Generalism and Particularism: The Cheng Brothers' Neo-Confucian Virtue Ethics. In Virtue Ethics and Confucianism, eds. Stephen Angle and Michael Slote, 162-170. New York, Abingdon: Taylor \& Francis Group.

Hughes, W., D. Punter and A. Smith. Eds. (2016). The Encyclopedia of the Gothic. Malden, MA: Wiley Blackwell.

Hwang, K.-K. (1999). Filial piety and loyalty: Two types of social identification in Confucianism. Asian Journal of Social Psychology 2: 163-183.

Ikels, C. (2004). Filial Piety: Practice and Discourse in Contemporary East Asia. Stanford, CA: Stanford University.

Ivanhoe, P. J. (2000). Confucian moral self cultivation. Indianapolis, IN: Hackett.

Ivanhoe, P. J. (2007). Filial piety as a virtue. In Working virtue: Virtue ethics and contemporary moral problems, eds. Rebecca L. Walker and Philip J. Ivanhoe, 297-312. Oxford: Oxford University Press.

Judy, R. (2011). The Cultivation of Mastery: Xiushen and the Hermeneutics of the Self in Early Chinese Thought. Intertexts 15.1: 1-19. 
Kao, K. S. Y. (1985). Classical Chinese Tales of the Supernatural and the Fantastic: Selections from the Third to the Tenth Century. Bloomington: Indiana University Press.

Kao, K. S. Y. (2002). Domains of Moral Discourse: Self, History, and Fantasy in 'Fengshen yanyi'. Chinese Literature: Essays, Articles, Reviews 24: 75-97.

Keown, D. (2004). Pure Land. A Dictionary of Buddhism. https://wwwoxfordreferencecom.ezproxy.lancs.ac.uk/view/10.1093/acref/9780198605607.00 1.0001/acref-9780198605607-e1458? rskey=D4xMW8\&result $=4$.

Kern, M. (2015). The 'Masters' in the Shiji. T'oung Pao 4-5: 335-362.

Kohn, L. (2004). Immortal parents and universal kin: family values in medieval Daoism. In Filial Piety in Chinese Thought and History, eds. Alan Chan and Sor-Hoon Tan, 91-109. London: Taylor \& Francis Group.

Kunio, M. (2004). Filial piety and 'authentic parents' in religious Daoism. In Filial Piety in Chinese Thought and History, eds. Alan Chan and Sor-Hoon Tan, 110-121. London: Taylor \& Francis Group.

Larm, J. (2012). Confucianism. In Encyclopedia of Global Studies, eds. Helmut K. Anheier, Mark Juergensmeyer and Victor Faessel, 266-269. Thousand Oaks, CA: SAGE Reference.

Lee, L.-L. (2009). Inventing Familial Agency from Powerlessness: Ban Zhao's Lessons for Women. Western journal of communication 73 (1): 47-66.

Leeming, D. (2002). Pure Land. A Dictionary of Asian Mythology. https://www-oxfordreference-

com.ezproxy.lancs.ac.uk/view/10.1093/acref/9780195120523.00 1.0001/acref-9780195120523-e-354?rskey=D4xMW8\&result=1 .

Leeming, D. (2005). Pure Land. The Oxford Companion to World Mythology. https://www-oxfordreferencecom.ezproxy.lancs.ac.uk/view/10.1093/acref/9780195156690.00 $1.0001 /$ acref-9780195156690-e1316 ? rskey=D4xMW8\&result $=2$.

Legge, J. (1969). Trans. The Text of the Yi King. New York: Paragon Book Reprint Corporation. 
Li, F. (2011). Pu Songling xiaoshuo Liaozhai zhiyi zhongde fojiao sixiang wenhua tanxi [Exploration of Buddhist culture and thought in Strange stories from a Chinese studio by Pu Songling]. Journal of Yunnan RTV University 13.3: 36-39.

Liu, J. and X. Cao. (2014). Daxue xiushenguan tanxi [Discussion on the idea of self-cultivation in Great Learning]. Journal of Social Science of Harbin Normal University 02: 18-20.

Li, L. (2005). Ershi shiji Puxue yanjiu de lichengbei-Du 'Pu Songling Zhi' zhaji [The milestone of $\mathrm{Pu}$ study in the $20^{\text {th }}$ centuryReading the 'Pu Songling record']. Study on Pu Songling 4: 202209.

Li, M. (1985). Qiantan Liaozhai Zhiyi zhong Yishi Shi yue [Discussing Yishi Shi yue in Liaozhai]. Jianghuai Tribune 02: 84-87.

Li, W. (2004). Yingguo gete xiaoshuo yu zhongguo liuchao zhiguai xiaoshuo bijiao yanjiu [Comaparative study between British gothic novels and Chinese Six Dynasties zhiguai novels]. Beijing: China Social Sciences Press.

Li, X. (2013). Cong Liaozhai zhiyi kan Pu Songling dui daojiao guannian de chaoyue [Discussing the development of Taoist thinking of Pu Songling in Liaozhai zhiyi]. Journal of Taiyuan Normal University 12.3: 65-67.

Liao, Y. (2013). Daojiao xiaodao sixiang de xiandai yiyi [The modern significance of Taoist filial piety thinking]. Journal of Tanshan College 26.1: 54-57.

Louie, K. and L. Edwards. Eds. and Trans. (1996). Censored by Confucius: ghost Stories by Yuan Mei. Armonk, New York: M. E. Sharpe.

Lu, T. (2011). The literary culture of the late Ming (1573-1644). In The Cambridge History of Chinese Literature, eds. Kang-i Sun Chang and Stephen Owen, 63-151. Cambridge: Cambridge University Press.

Mann, S. (2002). Grooming a daughter for marriage: Brides and wives in the mid-Qing period. In Chinese femininities/Chinese masculinities: A reader, eds. Susan Brownell and Jeffery Wasserstrom, 93-119. London: University of California Press.

Mou, B. (2009). Classical Confucianism. In Chinese Philosophy A-Z, 25-26. Edinburgh: Edinburgh University Press. 
Neville, R. C. (2011). Confucian Humaneness (REN) Across Social Barriers. In Confucianism and Spiritual Traditions in Modern China and Beyond: Confucianism and Spiritual Traditions In Modern China and Beyond, eds. Fenggang Yang and Joseph Tamney, 295-308. Leiden: BRILL.

Ng, R. M.-C. (2009). College and Character: What Did Confucius Teach Us About the Importance of Integrating Ethics, Character, Learning, and Education? Journal of College and Character 10.4. DOI: $10.2202 / 1940-1639.1045$.

Nichols, R. (2011). A Genealogy of Early Confucian Moral Psychology. Philosophy East and West 61.4: 609-629.

Nienhauser, W. H. Jr. (2010). Tang Dynasty Tales: A Guided Reader. Singapore: World Scientific Públishing Company.

Nuyen, A. T. (2004). The contemporary relevance of the Confucian idea of filial piety. Journal of Chinese Philosophy 31: 433-450.

Plopper, C. H. (1926). Chinese Religion Seen through the Proverb. Shanghai: The China Press.

Pohl, K.-H. (1999). Chinese Thought in a Global Context: A Dialogue Between Chinese and Western Philosophical Approaches. Leiden: Brill.

Qin, W. (2004). Liaozhai zhiyi fojiao sixiang qiantan-jianlun Pú Songling chuangzuode zhuguan mingyi [Briefly explore the Buddhist ideas of the ghost lore-concurrently discuss the Púrpose of Pú Songling's creation]. Journal of Hechi University 05: 34-37.

Riegel, J. 2010. Yuan Mei 袁枚 (1716-1798) and a Different 'Elegant Gathering'. Chinese Literature: Essays, Articles, Reviews 32: $95-$ 112.

Rosenlee, L.-H. L. (2006). Confucianism and Women: A Philosophical Interpretation. Albany: State University of New York Press.

Santangelo, P. and B. Yan. (2013). Zibuyu, 'What The Master Would Not Discuss', According to Yuan Mei (1716-1798): A Collection of Supernatural Stories. Leiden/Boston: Brill.

Schopen, G. (1984). Filial Piety and the Monk in the Practice of Indian Buddhism: A Question of 'Sinicization' Viewed from the Other Side. T'oung Pao 70.1/3: 110-126. 
Shan, C. (2012a). Major Aspects of Chinese Religion and Philosophy: Dao of Inner Saint and Outer King. Heidelberg: Springer.

Shan, C. (2012b). Political Personality Revealed in the Great Learning (daxue). Major Aspects of Chinese Religion and Philosophy: 277293.

Shan, C. (2012c). The Basic Spirit of Chinese Culture and National Faith. In Major Aspects of Chinese Religion and Philosophy. Berlin and Heidelberg: Springer.

Shang, B. (2018). Unnatural narratology and Zhiguai tales of the six dynasties in China. Neohelicon 45: 179-190.

Shahar, M. (2013). Violence in Chinese Religious Traditions. In The Oxford Handbook of Religion and Violence, eds. Michael Jerryson, Mark Juergensmeyer and Margo Kitts. DOI: 10.1093/oxfordhb/9780199759996.013.0009.

Shun, K.-L. (2002). Ren and Li in the Analects. In Confucius and the Analects: New Essays, ed. Bryan W. Van Norden, 53-72. Oxford: Oxford University Press.

Slingerland, E. (2011). 'Of What Use Are the Odes?' Cognitive Science, Virtue Ethics, and Early Confucian Ethics. Philosophy East and West 61.1: 80-109.

Strong, J. (1983). Filial Piety and Buddhism: The Indian Antecedents to a 'Chinese' Problem. In Traditions in Contact and Change, eds. Peter Slater and Donald Wiebe, 171-86. Waterloo: Wilfred Laurier University Press.

Sun, X. (2012). Lun ruxue zai sanjiaoheyi zhong de zhudao zuoyong [The dominant function of Confucianism in Sanjiaoheyi]. Theoretical Exploration 06: 37-39.

Sung, K.-t. (2003). Filial Piety: Buddhists' Way in East Asia, Journal of Religious Gerontology 14:4: 95-111.

Tan, C. (2017). A Confucian perspective of self-cultivation in learning: Its implications for self-directed learning. Journal of Adult and Continuing Education 23.2: 250-262.

Tan, J. (2011). Bojiao baoen guan yu fojiao xiaodao guan zhi bijiao [Comparing thankfulness with filial piety in Buddhism]. Journal of Xiaogan University 05: 10-14.

Tan, S.-h. (2018). Rethinking Confucianism's Relationship to Global Capitalism: Some Philosophical Reflections for a Confucian Critique of Global Capitalism. In Confucianisms for a changing

188 | VOL. 10 NO. 2 DECEMBER 2021 
world cultural order, eds. Roger T. Ames and Peter D. Hershock, 9-28. Honolulu: University of Hawaii Press.

Teiser, S. F. (1988). The Ghost Festival in Medieval China. Princeton: Princeton University Press.

Teiser, S. F. (1996). Introduction: The Spirits of Chinese Religion. In Religions of China in Practice, ed. Donald S. Lopez, Jr., 3-37. Princeton: Princeton University Press.

Teo, S. (2006). Pu Songling and the Spider. In King Hu's A Touch of Zen, 17-28. Hong Kong: Hong Kong University Press.

Theiss, J. M. (2002). Femininity in flux: Gendered virtue and social conflict in the mid-Qing courtroom. In Chinese femininities/Chinese masculinities: A reader, Susan Brownell and Jeffery Wasserstrom, eds, 47-66. London: University of California Press.

Tucker, J. A. (1997). Reviewed Work: Censored by Confucius: Ghost Stories by Yuan Mei. China Review International 4.2: 487-494.

Van Norden, B. (2019). Mencius. In Stanford Encyclopedia of $\begin{array}{llll}\text { Philosophy, ed. } & \text { Edward }\end{array}$ https://plato.stanford.edu/entries/mencius/.

Wang, A. (2020). Unveiling Religious Ideology of Chinese Aristocracy in Imperial Qing from a Literary Perspective. Frontiers of Literary Studies in China 14.1: 99-133.

Wang, Z. (2006). Jin wushi nian liaozhai zhiyi zai riben de chuanbo he yanjiu [The spread and study of Liaozhai Zhiyi in Japan in the past 50 years]. Journal of Fujian Normal University 06: 109-113.

Wilkinson, B. (1996). Culture, institutions and business in East Asia. Organization Studies 17(3): 421-447.

Wilson, L. (2013). Introduction: Family and the Construction of Religious Communities. In Family in Buddhism, ed. Liz Wilson, 1-20. Albany: State University of New York Press.

Wilson, L. (2014). Buddhism and Family. Religion Compass 8/6: 188198.

Wong, D. (2020). Chinese Ethics. In The Stanford Encyclopedia of Philosophy (Summer 2020 Edition), ed. Edward N. Zalta. https://plato.stanford.edu/archives/sum2020/entries/ethicschinese/. 
Wu, D. (2014). Daojiao xiaodaoguan yanjiu [Research on Daoist filial piety]. Charming China 08: 270.

$\mathrm{Wu}$, M. (2017). The Process of Self-Cultivation and the Mandala Model of the Self. Frontiers in Psychology 08. https://doi.org/10.3389/fpsyg.2017.00024.

Xi, T. (2018). Lun Liaozhai zhiyi zhongde ceng dao xingxiang [On images of monks and Taoist priests in Strange tales from Liaozhi]. Journal of Neijiang Normal University 05: 26-31.

Xiao, Q. (1997). Wenchang xiaojing de daojiao xiaodaoguan [Daoist view on filial piety in Wenchang xiaojing]. Morality and Civilization 06: 16-19.

Xie, W. (2014). Encountering Ghost Princesses in Sou shen ji: Rereading Classical Chinese Ghost Wife Zhiguai Tales. In Unsettling Assumptions: Tradition, Gender, Drag, eds. Pauline Greenhill and Diane Tye, 244-260. Logan: Utah State University Press.

Xing, G. (2005). Filial Piety in Early Buddhism. Journal of Buddhist Ethics 12: 82-106.

Xing, G. (2010). A Buddhist-Confucian controversy on filial piety. Journal of Chinese Philosophy 37.2: 248-260.

Yan, H. K. T. (2017). Is filial piety a virtue? A reading of the Xiao Jing (Classic of Filial Piety) from the perspective of ideology critique. Educational Philosophy and Theory 12: 1184-1194.

Yang, G. (2004). Liaozhai zhiyi de daojiao xianjing ticai qianshi [Strange stories from a lonely studio: Taoism' Fairyland subject matter simply explain]. Journal of Zaozhuang Teachers' College 21.4: $28-30$.

Yang, L.-s. (1976). The concept of Pao as a basis for social relations in China. In Chinese thought and institutions, ed. John K. Fairbank, trans. Renni Liu, Changguo Duan and Yongtang Zhang, 349-372. Taipei: Linking Públishing Company.

Yang, S. (2011). Cong Liaozhai zhiyi kan Pu Songling dui xiaodao de tuichong yu hongyang [ $\mathrm{Pu}$ Songling's high praise and promotion of filial piety in Strange tales from a lonely studio]. Journal of Xiaogan University 31.4: 17-21.

Yang, S. (2016). Cong Liaozhai zhiyi kann Pu Songling de chongfo sixiang [Analysing Pu Songling's Buddhist thought in Liaozhai zhiyi]. Journal of Zibo Normal College 04: 67-70. 
Yang, S.-j. (2017). The Reconciliation of Filial Piety and Political Authority in Early China. Dao 16: 187-203.

Yao, X. (1995). Jen, Love and Universality-Three Arguments. Concerning Jen in Confucianism. Asian Philosophy 5: 181-195.

Yu, A. C. (1987). 'Rest, Rest, Perturbed Spirit!' Ghosts in Traditional Chinese Prose Fiction. Harvard Journal of Asiatic Studies 47.2: 397-434.

Yuan, S. (1984). Zhongguo dudian wenxue mingzhu jieshao zhiyi Liaozhai Zhiyi jiqi zuozhe Pu Songling [Introduction of one of the masterpieces of traditional Chinese literature, Liaozhai Zhiyi and its author Pu Songling]. Zhongguo Jianshe 02: 3-13.

Yuan, S. (1999). Wenxue shixue de mingqing xiaoshuo yanjiu [MingQing fiction study of the literary history]. Jinan: Qilu Press.

Yuan, S. and Z. Xu. (2000). Pu Songling pingzhuan [Biography of Pu Songling]. Nanjing: Nanjing University Press.

Zeitlin, J. (1988). Pu Songling's Liaozhai zhiyi and the Chinese Discourse on the Strange. PhD thesis. Harvard University.

Zeitlin, J. (1993). Historian of the Strange: Pu Songling and the Chinese Classical Tale. Stanford University Press.

Zhang, L. (2015). Wenchang xiaojing xiaodao sixiang yanjiu [Research on the thinking of filial piety in Wenchang xiaojing]. Contemporary Youth 08: 286-287.

Zhang, X. (2014). Zhongyong de xiushen sixiang [On the theory of selfcultivation in Zhong Yong]. Journal of Yibin University 01: 4589.

Zhang, X. (1989). Xieyi xiangfu, zhuke hutuo-Lun Liaozhai Zhiyi zhongde Yishi Shi yue [Comination of depicting and commenting as well as main and complement-Discussing the Yishi Shi yue in Liaozhai]. Study on Pu Songling 02: 184-201.

Zhang, Y. (2003). Lun rujia sixiang dui liaozhai zhiyi de shentou [Analysing the influence of Confucian thinking on Liaozhai zhiyi]. Study on Pu Songling 01: 5-15.

Zhang, Z. (2014). Buddhism and Tales of the Supernatural in Early Medieval China: A Study of Liu Yiqing's (403-444) Youming Lu. Leiden; Boston: Brill.

Zheng, C. and S. Zhan. (2011). Daojiao xiaodaoguan chuyi [Discussion of Taoist filial conception]. Religious Studies 01: 218-221.

Heritage of Nusantara: 
Syncretism of Confucianism, Buddhism and Daoism ...

Zheng, X. (2001). Liaozhai Zhiyi Yishi Shi yue xushi shixing de tanxi [Discovery of narrative styles of Yishi Shi yue in Liaozhai Zhiyi]. Study on Pu Songling 04.

Zhao. F. (1984). Yishi shi yue zai Liaozhai Zhiyi zhong de zuoyong [The function of Yishi Shi yue in Liaozhai Zhiyi]. Study on $\mathrm{Pu}$ Songling 4.

Zhao, X. (2005). Classical Chinese Supernatural Tales: A Morphological Study. Lewiston, NY: Edwin Mellen Press.

Zhou, S. (2012). Lun daojiao xiaodaoguan de xiandai fansi jiazhi [Discussion on modern values of Daoist filial piety]. Journal of Hunan Mass Media Vocational Technical College 12.2: 77-80.

Zou, Z. (2019). Liaozhai xue yehua [Talk on study of Liaozhai]. Study on Pu Songling 02: 5-17. 